\title{
HUBUNGAN KELEKATAN TERHADAP KEPUASAN HUBUNGAN ROMANTIS PADA MAHASISWA POLITEKNIK KESEHATAN Dr. SOEPRAOEN MALANG
}

\author{
Shinta Renanda
}

\section{* Corresponding Author:} STIKES dr. Soepraoen Malang Email:

shintarenanda@gmail.com

\begin{abstract}
Abstrak. Penelitian ini bertujuan untuk melihat hubungan gaya kelekatan terhadap kepuasan hubungan romantis pada mahasiswa yang dimediasi oleh kepercayaan. Populasi dalam penelitian ini adalah mahasiswa D3 Kebidanan semester 1 angkatan 2017 Poltekkes RS dr. Soepraoen Malang yang berjumlah 39 orang. Data dikumpulkan melalui angket menggunakan skala Relationship Style Questionnaire untuk mengukur gaya kelekatan, skala kepercayaan dan Relationship Assesment Scale untuk mengukur kepuasan hubungan romantis. Penelitian ini adalah jenis penelitian kuantitatif . Penelitian ini menggunakan teknik sampling jenuh dan pengumpulan data menggunakan skala likert, dengan program SPSS versi 20,2. Hasil analisis penelitian menunjukkan bahwa terdapat hubungan kelekatan, kepercayaan dengan kepuasan hubungan romantis dengan nilai $p(0,003<0,05)$.
\end{abstract}

Kata Kunci: Kelekatan, Kepuasan, Hubungann Romantis

Abstract. This study aims to see the relationship of attachment style to
the satisfaction of romantic relationships among students who is mediat-
ed by trust. The population in this study were students of D3 Midwifery
semester 1 class 2017 Poltekkes RS dr. Soepraoen Malang, amounting
to 39 people. Data were collected through a questionnaire using the Re-
lationship Style Questionnaire scale to measure attachment style, trust
scale and the Relationship Assessment Scale to measure the satisfaction
of romantic relationships. This research is a type of quantitative research.
This study used a saturated sampling technique and data collection using
a Likert scale, with the SPSS program version 20.2 . The results of the
analysis showed that there was a relationship between attachment, trust
and satisfaction with romantic relationships with p value $(0.003<0.05)$.
Keywords: Attachment, Satisfaction, Romantic Relationships

\section{PENDAHULUAN}

Kepercayaan merupakan outcomes dari hubungan yang terjalin kuat, dimana masing-masing pasangan merasa bahwa mereka dapat bergantung satu sama lain. Kepercayaan merupakan salah satu komponen dari hubungan yang terjalin kuat antara seseorang dan figure attachment mereka. Dasar pembentukan rasa aman menekankan pada keyakinan tentang ke- beradaan figure attachment pada saat yang dibutuhkan. Dengan kata lain, rasa percaya terhadap figure attachment berhubungan dengan pengalaman-pengalaman positif sebelumnya yang berhubungan dengan terbentuknya kepercayaan. Kepercayaan merupakan salah satu kualitas dalam hubungan intim yang seringkali dikaitkan dengan cinta dan janji yang merupakan dasar hubungan yang ideal. Kepercayaan 
terhadap pasangan akan meningkat apabila pasangan dapat memenuhi pengharapan individu dan bersungguh-sungguh peduli terhadap pasanganketika situasi memungkinkan individu untuk tidak memperdulikan mereka (Rempel, et al, 1985).

Menurut Wieselquist (2009) kepercayaan memprediksi kepuasaan hubungan romantis dan kepercayaan adalah hal yang paling penting dalam sebuah hubungan. Menurut Simpson (2007) Ketika hubungan yang diisi dengan kepercayaan, mungkin akan berkurangnya rasa keragu-raguaan dan ketidakpuasan pada diri sendiri khususnya dengan citra tubuh.

Hazan \& Shaver (1987) menjelaskan bahwa hubungan romantis pada masa remaja dan dewasa dapat dikonseptualisasikan sebagai proses kelekatan sesuai dengan teori kelekatan Bowlby tentang kelekatan pada masa kanak dengan figur lekat (orangtua). Teori ini dapat terbentuk atas dasar pemahaman bahwa semenjak masa remaja, figur lekat seseorang mulai ditransfer kepada teman maupun pasangan dan pada masa "transfer" inilah perilaku akan muncul sesuai dengan kelekatan yang dimilikinya, aman ataukah tidak aman.

Gaya kelekatan adalah derajat keamanan yang dialami dalam hubungan interpersonal. Gaya-gaya yang berbeda pada awalnya dibangun pada saat masih bayi, tetapi perbedaan dalam kelekatan tampak mempengaruhi perilaku interpersonal sepanjang hidup (Baron, 2004). Jean (1991), dalam jurnalnya mengatakan bahwa kepuasaan hubungan mempunyai pengaruh yang positif dengan gaya kelekatan. Hal ini juga sama dengan penelitian Judith (2007) yang menyatakan adanya gaya kelekatan dengan cinta romantis. Dari penjelasan diatas peneliti menyimpulkan bahwa ketika pasangan memiliki gaya kelekatan yang kuat pada pasangannya maka akan menimbulkan kepercayaan pada pasangan dimana ketika pasangan yang sudah memiliki gaya kelekatan dan kepercayaan maka kepuasan hubungan romantis itu akan terpenuhi. Oleh karena itu peneliti menggagaskan penelitian yang berjudul Hubungan Kelekatan dan Kepercayaan Terhadap Kepuasan Hubungan Romantis Pada Mahasiswa.

\section{Gaya Kelekatan}

Menurut Bartolomew \& Grifiin (1994) ada 4 gaya kelekatan Relationships Style Questionnaire (RSQ). yaitu: Gaya Kelekatan Aman (Secure Attachment Style). Yaitu seseorang dengan gaya kelekatan aman memiliki self-esteem yang tinggi dan positif terhadap orang lain, sehingga ia mencari kedekatan interpersonal dan merasa nyaman dalam hubungan. Orang-orang dengan gaya kelekatan aman melaporkan memiliki hubungan yang hangat dengan orang tua mereka dan mempersepsikan kehidupan keluarga mereka di masa lampau dan masa kini secara positif. Dibandingkan dengan gaya kelekatan yang lain, seseorang yang memiliki gaya kelekatan aman akan lebih tidak mudah marah, lebih tidak mengatribusikan keinginan bermusuhan dengan orang lain, dan mengharapkan hasil yang positif dan konstruktif dari konflik. Gaya Kelekatan Terokupasi (Preoccupied Attachment Style), gaya kelekatan ini didefinisikan sebagai pandangan negatif mengenai diri yang dikombinasikan dengan harapan yang positif bahwa orang lain akan mencintai dan menerima. Sebagai akibatnya, individu yang terokupasi mencari kedekatan dalam hubungan, tetapi mereka juga mengalami kecemasan dan rasa malu karena mereka merasa tidak pantas menerima cinta dari orang lain. Tekanan mengenai kemungkinan ditolak terjadi secara ekstrem. Kebutuhan untuk dicintai dan diakui ditambah dengan adanya self-criticism mendorong terjadinya depresi setiap kali suatu hubungan menjadi buruk. Orang dengan gaya kelekatan ini mempunyai karakteristik kurang percaya terhadap keberadaan pasangan dan memiliki ketakutan untuk ditolak.

Gaya Kelekatan Takut-Menghindar (Fearful-Avoidant Attachment Style). Seseorang dengan gaya kelekatan ini memiliki self-esteem yang rendah dan negatif terhadap orang lain. Dengan meminimalkan kedekatan interpersonal dan menghindari hubungan akrab, mereka berharap dapat menghindari diri mereka dari rasa sakit akibat penolakan. Individu dengan gaya kelekatan ini menggambarkan orang tua mereka secara negatif, memendam perasaan bermusuhan dan marah yang tidak disadari, dan lebih tidak mengalami keintiman dan kesenangan dalam berinteraksi dengan pasangan romantis yang sekarang dimiliki atau yang potensial.

Gaya kelekatan ini diasosiasikan dengan hubungan interpersonal yang negatif, rasa cemburu, dan penggunaan alkohol untuk mengurangi kecemasan mereka. Orang dengan gaya kelekatan ini juga memiliki karakteristik kurang percaya terhadap keberadaan pasangan, memiliki ketakutan ditolak, dan memiliki ketakutan ditinggalkan. Dan terakhir adalah Gaya Kelekatan Menolak (Dissmisive-Avoidant Attachment Style). Gaya kelekatan ini digambarkan sebagai pandangan seseorang yang sangat positif terhadap dirinya namun kadang kala tidak realistis. Selain itu, pandangannya tentang dirinya berbeda jauh dengan pandangan orang lain mengenai dirinya. Individu dengan gaya kelekatan ini menganggap dirinya berharga, independen, sangat layak untuk mendapatkan hubungan dekat. Orang lain lebih mungkin untuk melihat mereka secara lebih tidak positif dan mendeskripsikan mereka sebagai tidak ramah dan memiliki ketrampilan sosial yang terbatas.

\section{Kepercayaan}

Kepercayaan adalah kemauan seseorang untuk bertumpu pada orang lain dimana kita memiliki keyakinan padanya. Kepercayaan merupakan kondisi mental yang didasarkan oleh 
situasi seseorang dan konteks sosialnya. Ketika seseorang mengambil suatu keputusan, ia akan lebih memilih keputusan berdasarkan pilihan dari orang- orang yang lebih dapat ia percaya dari pada yang kurang dipercayai (Moorman, 1993).

Menurut Rousseau et al (1998), kepercayaan adalah wilayah psikologis yang merupakan perhatian untuk menerima apa adanya berdasarkan harapan terhadap perilaku yang baik dari orang lain. Kepercayaan konsumen didefinisikan sebagai kesediaan satu pihak untuk menerima resiko dari tindakan pihak lain berdasarkan harapan bahwa pihak lain akan melakukan tindakan penting untuk pihak yang mempercayainya, terlepas dari kemampuan untuk mengawasi dan mengendalikan tindakan pihak yang dipercaya (Mayer et al, 1995).

Menurut Rempel (1985) ada 3 komponen kepercayaan. Ketiga komponen itu adalah Predictability, Dependability, dan Faith. Keadaan dapat diramalkan (Predictability), Seseorang yang dapat diramalkan adalah seseorang yang mempunyai perilaku yang konsisten walaupun perilaku tersebut terus menerus buruk (Robinson, 1990). Keadaan dapat diandalkan (Dependability) yaitu keadaan dapat diandalkan. Berhubungan dengan perasaan yang timbul bahwa pasangannya adalah seseorang seorang yang bisa diandalkan (Robinson, 1990. Keyakinan (Faith). Keyakinan berupa kemampuan seseorang dalam pengambilan risk taking, indepth relationship, percaya pada janji yang diberikan dengan mengorbankan penghargaan seseorang untuk sebuah keuntungan yang akan datang.

\section{Kepuasan Hubungan Romantis}

Pada pasangan yang berpacaran, hubungan antara mereka melibatkan keintiman yang lebih intensif dan sangat mendalam. Menurut Harrison (2000), pasangan romantis atau pacar didefinisikan sebagai seseorang yang membuat kita tertarik secara fisik, menginginkan kontak yang lebih intim (berpegangan tangan, berpelukan, dan lain-lain), keinginan untuk menjadi lebih dari sekedar teman, dan pergi bersama dalam suatu kencan.

Kepuasaan merupakan perasaan yang dialami seseorang ketika keinginannya terpenuhi. Kepuasaan hubungan merupakan evaluasi intrapersonal seseorang dengan merasakan hal positif serta ketertarikannya pada hbungan yang ia jalani (Rusbult, 1983). Terkait dengan hubungan romantis, mka kepuasan dalam suatu hubungan aan dialami jika tujuan yang ingi dicapai dari hubungan tersebut dapat terpenuhi. Seseorang akan merasa puas dalam menjalani hubungan romantis ketika perbandingan antara keuntungan yang didapat dan kontribusi yang diberikan dalam berhubungan dalam kondisi seimbang atau sama besar untuk tiap pasangan (Regan, 2003).

Hendrick (1988) mengemukakan 3 kom- ponen yang dapat mengukur kepuasan dalam hubungan berbapacaran, yaitu : cinta (love). Cinta dapat diekspresikan melalui banyak hal, seperti melalui komunikasi verbal dengan mengatakan perasaan sayang kepda pasangan, ataupun melalui komunikasi noverbal berupa ekspresi afeksi, seperti genggaman, pelukan, ciuman dan perasaan tenang serta bahagia ketika bersama orang yang dicintai. Masalah-masalah (problems). Masalah yang biasa terjai dalam suatu hubungan merupakan konflik yang terjadi karen perbedaan perilaku atau pandangan masing-masing individu. Dalam hubungan romantis individu ingin dapat dekat dan kooperatif serta memiliki persetujuan dengan orang lain namun di sisi lain individu menginginkan otonomi pribadi dengan kata lain memungkinkan terjadinya ketidaksetujuan dengan orang lain. Tetapi, adanya masalah dengan pasangan justru menyebabkan individu semakin dapat memahami karakter masing-masing. Masalah dapat menguatkan atau malah menghancurkan hubungan, tergantung bagaimana pasangan tersebut menyelesaikannya (William, Sawyer \& Wahlstrom, 2006). Dan yang terakhir adalah harapan-harapan (expectations). Seseorang akan merasa puas jika hubungan yang dijalaninya sesuai dengan harapan dan perkiraannya (Taylor, Peplau \& Sears, 2006). Harapan disini merupakan suatu keinginan atau tujun yang ingin dicapai seseorang dalam suatu hubungan.

\section{METODE \\ Sampel dan Populasi Penelitian}

Populasi dalam penelitian ini adalah mahasiswa D3 Kebidanan semester 1 angkatan 2017 Poltekkes RS dr. Soepraoen Malang yang berjumlah 40 orang. Menurut Arikunto (2005) apabila subjek penelitian kurang dari 100, lebih baik diambil semuanya sehingga penelitian ini merupakan penelitian populasi. Sehingga penentuan responden dipilih dengan cara menggunakan teknik sampling jenuh. Tenik sampling jenuh adalah teknik penentuan sampel jika semua anggota populasi digunakan sebagai sampel (Sugiyono, 2011).

Adapun dalam penelitian ini penyebaran angket disebar kepada 40 mahasiswa, namun yang kembali pada peneliti sebanyak 39 mahasiwa.

\section{Intrumen Penelitian \\ Gaya Kelekatan}

Skala Relationship Style Questionnaire digunakan untuk mengukur dimensi-dimensi terkait dengan positif atau negatif antara model diri dan orang lain. terdapat empat jenis model pernyataan tes sesuai dengan pengertian kelekatan menurut tokoh. Pada penelitian ini, gaya kelekatan dilihat dari model yang yang diusulkan oleh Griffin dan Bartholomew (1994). Model ini mengusulkan empat gaya kelekatan, yaitu kelekatan aman (secure), kelekatan terok- 
upasi (preoccupied), kelekatan takut-menghindar (fearful-avoidance), dan kelekatan menolak (dismissive). Pada skala ini, subjek diminta untuk memberi tanda silang pada angka yang paling menggambarkan perasaan subjek. Dimulai dari angka satu yang berarti sangat tidak menggambarkan perasaan subjek sampai angka lima yang berarti sangat menggambarkan perasaan subjek. Semakin tinggi skor subjek terhadap gaya kelekatan tertentu menunjukkan kecenderungan gaya kelekatan subjek. Skala ini terdiri dari 30 aitem. Skala Relationship Style Questionnaire (RSQ) ini berbentuk skala likert. Dalam pengisian skala ini, subjek diminta untuk merespon dengan memberikan tanda pada salah satu pilihan yang sesuai dengan diri subjek.

\section{Kepercayaan}

Dalam penelitian ini menggunakan skala likert yang dikembangkan oleh Rampel (1985) yang terdiri dari 17 aitem untuk mengukur kepercayaan interpersonal pada pasangan. Skala ini disusun berdasarkan 3 komponen yaitu dapat diramalkan (Predictability), dapat diandalkan (Dependability), dan keyakinan (Faith).

\section{Kepuasan Hubungan Romantis}

Dalam penelitian ini digunakan skala dari Hendrick (1988) berupa kuesioner Relationship Assesment Scale. Skala ini terdiri dari 7 aitem yang mengukur kepuasan seseorang dalam menjalin hubungan romantis yang ia jalani dengan pasangannya saat ini. Skala ini disusun berdasarkan komponen-komponen yang secara umum muncul dalam hubungan romantis seperti besarnya perasaan cinta, pemenuhan kebutuhan dan pengharapan, serta banyaknya masalah dalam suatu hubungan secara umum.

\section{Analisis Data}

Metode analisis data yang digunakan pada penelitian ini adalah analisis Regresi Linear Berganda, dengan bantuan program SPSS.22.

\section{HASIL DAN PEMBAHASAN Hasil}

Tabel 1. Hasil Analisis Regresi Kelekatan dan Kepuasan Hubungan Romantis

\begin{tabular}{cccc}
\hline No & Variabel & $\mathbf{R}^{2}$ & Sig \\
\hline $\mathbf{1}$ & $\begin{array}{c}\text { Kelekatan \& Kepuasan } \\
\text { Hubungan }\end{array}$ & .110 & .039 \\
\hline
\end{tabular}

Berdasarkan hasil analisis diatas bahwa terdapat hubungan kelekatan dengan kepuasan hubungan romantis dengan nilai $\mathrm{p}(0,039<0,05)$ - Dengan sumbangan variable bebas ke terikat sebesar $11 \%$.
Tabel 2. Hasil Analisis Regresi Kelekatan dan Kepercayaan

\begin{tabular}{cccc}
\hline No & Variabel & $\mathbf{R}^{2}$ & Sig \\
\hline $\mathbf{1}$ & Kelekatan \& Kepercayaan & .129 & .025 \\
\hline
\end{tabular}

Berdasarkan hasil analisis diatas bahwa terdapat hubungan kelekatan dengan kepercayaan dengan nilai $p(0,025<0,05)$. Dengan sumbangan variable bebas ke terikat sebesar $12,9 \%$.

Tabel 3. Hasil Analisis Regresi Kepercayaan dan Kepuasaan Hubungan Romantis

\begin{tabular}{cccc}
\hline No & Variabel & $\mathbf{R}^{2}$ & Sig \\
\hline $\mathbf{1}$ & $\begin{array}{c}\text { Kepercayaan \& Kepuasaan } \\
\text { Hubungan Romantis }\end{array}$ &. .125 & .027 \\
\hline
\end{tabular}

Berdasarkan hasil analisis diatas bahwa terdapat hubungan kepercayaan dengan kepuasan hubungan romantis dengan nilai p $(0,027<$ $0,05)$. Dengan sumbangan variable bebas ke terikat sebesar $12,5 \%$.

Tabel 4. Hasil Analisis Regresi Kelekatan, Kepercayaan Terhadap Kepuasaan Hubungan Romantis

\begin{tabular}{cccc}
\hline No & Variabel & $\mathbf{R}^{2}$ & Sig \\
\hline $\mathbf{1}$ & $\begin{array}{c}\text { Kelekatan, Kepercayaan \& } \\
\text { Kepuasan Hubungan Romantis }\end{array}$ & .254 & .003 \\
\hline
\end{tabular}

Berdasarkan hasil analisis diatas bahwa terdapat hubungan kelekatan, kepercayaan dengan kepuasan hubungan romantis dengan nilai p $(0,003<0,05)$. Dengan sumbangan variable bebas ke terikat sebesar $25,4 \%$.

\section{Pembahasan}

Kelekatan sering kali berbicara tentang hubungan antara orang tua dan anak, tapi kelekatan juga bisa dikaitkan dengan hubungan antar orang dewasa yang romantis (Bowbly, 1980). Perilaku kelekatan merupakan bentuk pencarian kedekatan seseorang dengan orang lain. Kelekatan ada agar seseorang mampu bertahan hidup, karena dalam kelekatan ada rasa aman dan terpenuhinya kebutuhan dari figur yang dilekatkan. Ketika seseorang telah lekat dengan orang lain, ia akan merasa aman, terlindungi, dan terpenuhi kebutuhan afeksinya. Kelekatan ini bersifat menetap, intens, dan terus menerus.

Menurut Santrock (2007), kelekatan adalah ikatan emosional yang erat antara dua orang. Kelekatan ini mengacu pada suatu relasi antara dua orang yang memiliki perasaan yang kuat satu sama lain dan melakukan banyak hal bersama untuk melanjutkan relasi itu. Anak yang mendapatkan kelekatan (Attachment) yang cukup, akan merasa dirinya aman (Secure) dan lebih positif terhadap kelompoknya, menunjukkan ketertarikan yang lebih besar terhadap orang lain di dalam mengajak bermain atau ke- 
tika digendong. Begitu juga dengan seseorang yang menjalin hubungan ia akan merasa dirinya aman dan menunjukkan rasa ketertarikan dan kepercayaan pada pada pasangannya. Menurut Cox (2001) kelekatan sebagai ikatan emosional yang kuat dengan orang lain. Mereka memiliki ikatan emosional yang kuat oleh karena itu diantara keduanya akan memiliki rasa saling percaya satu sama lain. Hal ini sejalan dengan hasil analisis pada tabel 1 yang menyatakan ada hubungan antara kelekatan dengan kepercayaan.

Dalam perkembangan dewasa, kelekatan akan berperan ketika seseorang menjalin hubungan dekat dengan orang lain. Menurut Hazan dan Shaver (1994), pada anak figure care giver biasanya adalah orang tua tetapi pada kelekatan figur dewasa yang muncul secara umum adalah peer yang biasanya partner secara seksual. Dengan kata lain pada adult attachment, seseorang memiliki ikatan dengan seseorang yang sedang dalam hubungan pacaran. Hazan dan Shaver juga berpendapat bahwa ikatan awal pada masa infancy yang terbentuk dengan baik pada salah satu bentuk kelekatan maka akan berpengaruh pada adult attachment khususnya ketika menjalin hubungan romantis. Seperti pada tabel pertama ada hubungan antara kelekatan dengan kepuasaan hubungan romantis. Jika seseorang itu memiliki kelekatan satu sama lain maka akan merasakan kepuasan hubungan romantis diantara keduanya. Penelitian dari Brennan dan Shaver (1995) juga menyatakan adanya hubungan antara tipe attachment dengan kepuasan dalam hubungan dekat.

Pada tabel 3 terdapat hubungan yang signifikan antara kepercayaan dan kepuasaan hubungan romantis. Hal ini disebabkan kepercayaan memprediksi kepuasaan hubungan romantis dan kepercayaan adalah hal yang paling penting dalam sebuah hubungan. Menurut Simpson (2007) Ketika hubungan yang diisi dengan kepercayaan, mungkin akan berkurangnya rasa keragu-raguaan dan ketidakpuasan pada diri sendiri khususnya dengan citra tubuh. Menurut Lewicki (2000) fakor yang mempengaruhi kepercayaan adalah komunikasi, berbicara, bekerja, berkoordinasi, sifat kepribadian, konsisten yang mendominasi pengalaman. Menurut Rempel, et al (1985) yang menyatakan bahwa aspek dalam kepercayaan pasangan dibagi menjadi tiga yakni predictability yaitu perilaku konsisten, dependability yaitu keadaan yang dapat diandalkan dan faith (keyakinan).

\section{KESIMPULAN}

Pada penelitian ini kelekatan berhubungan dengan kepercayaan karna ketika seseorang mengalami kelekatan dan memiliki ikatan emosional yang kuat dengan pasangan seperti yang telah dijelaskan diatas maka seseorang itu akan merasa tertarik dan menaruh kepercayaan dengan pasangannya. Kelekatan juga mempengaruhi kepuasan hubungan romantis. Kelekat- an merupakan tingkah laku yang khusus pada manusia, yaitu kecenderungan dan keinginan seseorang untuk mencari kedekatan dengan orang lain dan mencari kepuasan dalam hubungan dengan orang tersebut (Soetjiningsih, 2012). Kepercayaan mempengaruhi kepuasaan hubungan romantis. Hal ini juga disebutkan dalam Menurut Kauffman (2000) yang berpendapat bahwa kepercayaan atau trus adalah aspek yang tertinggi dalam menjalin sebuah hubungan. Jadi kesimpulannya kepercayaan dapat memediasi hubungan antara kelekatan dan kepuasan hubungan romantis.

\section{REFERENSI}

Baron \& Byrne. (2004). Psikologi sosial Jilid 2. Jakarta: Erlangga

Brennan, K. A., \& Shaver, P. R. (1995). Dimensions of adult attachment, affect regulation, and romantic relationship functioning. Personality and Social Psychology Bulletin, (21), 267-283.

Griffin, D.W. and Bartholomew, K. (1994) The metaphysics of measurement: The case of adult attachment. In: Bartholomew, K. and Perlman, D., Eds., Attachment Processes in Adulthood, Advances in Personal Relationships. Jessica Kingsley Publishers, London, 17-52

Hazan, C., \& Shaver, P. R. (1987). Romantic love conceptualized as an attachment process. Journal of Personality and Social Psychology, (52), 511-524

Rempel, J.K., Holmes, J.G. \& Zanna, M.P. (1985). Trust in close relationships., 95-112. Journal of Personality and Social Psychology, 49(1), 95-112

Rousseau, D.M., S.B. Sitkin, R.S. Burt, and C. Camerer. 1998. Not So Different After All: A Cross-Discipline View of Trust. Academy of Management Review (23), 393-404.

Hendrick, S. S. (1988). A generic measure of relationship satisfaction. Journal of Marriage and the Family, (50), 93-98

Jean, R. H., \& Garth, J.O. (1991). Attachment styles and relationship satisfaction in the development of close relationship. New Zealand Journal of psychology (20), 56-62

Judith A. Feeney \& Patricia Noller (1992) Attachment style and romantic love: Relationship dissolution. Australian Journal of Psychology. (44:2), 69-74

Kauffman, M. H. (2000). Relational maintenance in long-distance relationships: staying close. Master of Science Thesis Blacksburg. Virginia.

Lewicki, R.J., \& Wiethoff, C. (2000). Trust, Trust Development, and Trust Repair. In M. Deutsch \& P.T. Coleman (Eds.) Handbook of research conflict resolution: Theory and practice, 86-107

Mayer, R.C., Davis, J. H., dan Schoorman, F. D., 
1995. An Integratif Model of Organizational Trust. Academy of Management Review 30(3), 709-734

Moorman. C., Deshpande, R., \& Zaltman, G. (1993). Actors affecting trust in market relationship: Journal of Marketing.Vol 58

Regan, P. (2003). The Mating Game: A Primer on Love, Sex, and Marriage. SAGE Publications, Inc

Rusbult, C. E. 1983. A longitudinal test of the investmentmModel: The development (and deterioration) of satisfaction and commitment in heterosexual involvements. Journal of Personality and Social Psychology, 45(1), 101-117

Simpson, J. A., Collins, W. A., Tran, S \& Haydon K. C.(2007). Attachment and the experience and expression of emotions in romantic relationships: a developmental perspective. $J$ Pers Soc Psychol, 92(2), 355-67.

Soetjiningsih. ( 2012). Perkembangan Anak dan Permasalahannya dalam Buku Ajar I Ilmu Perkembangan Anak Dan Remaja. Jakarta : Sagungseto. 86-90

Taylor, S, E. , Peplau, L. A. , \& Sears, D. O. (2006). Social psychology 12th ed. New Jersey. Pearson Education Group, Inc

Wieselquist, J. (2009). Interpersonal forgiveness, trust, and the investment model of commitment. Journal of Social and Personal Relationships, 26(4), 531- 5

Williams, B. K. , Sawyer, S. C., \& Wahlstorm, C. M. (2006). Marriages, families, $\mathcal{E}$ intimate relationship: A practical introduction. Boston: Pearson Education, Inc 